\title{
Guanine Nucleotide-Binding Protein G(z) Subunit Alpha
}

National Cancer Institute

\section{Source}

National Cancer Institute. Guanine Nucleotide-Binding Protein G(z) Subunit Alpha. NCI

Thesaurus. Code C26188.

Guanine nucleotide-binding protein $\mathrm{G}(\mathrm{z}$ ) subunit alpha (355 aa, $\sim 41 \mathrm{kDa}$ ) is encoded by the human GNAZ gene. This protein is involved in G protein-dependent signaling. 